2. To: (Receiving Organization)

Distribution

\section{Proj./Prog./Dept./Div.:}

Interim Stabilization

8. Originator Remarks:

This document identifies the tasks that are involved in preparing Stabilization's schedule for saltwell pumping.

\section{Receiver Remarks:}

11A. Design Baseline Document? $\bigcirc$ Yes

For approval and release. the "standby" portable exhauster (POR05 skid C) to support Interim
3. From: (Originating Organization)

Equipment Engineering

6. Design Authority/Design Agent/Cog. Engr.:

J.R. Kriskovich
4. Related EDT No::

$\mathrm{N} / \mathrm{A}$

7. Purchase Order No.:

$\mathrm{N} / \mathrm{A}$

9. Equip./Component No.:

POR05 skid C

10. System/B/dg./Facility:

$N / A$

12. Major Assm. Dwg. No.:

H-14-100867

13. Permit/Permit Application No.:

$\mathrm{N} / \mathrm{A}$

14. Required Response Date:

\section{$9 / 22 / 99$}

\begin{tabular}{|c|c|c|c|c|c|c|c|c|}
\hline 15. & \multicolumn{4}{|c|}{ DATA TRANSMITTED } & (F) & (G) & (H) & (l) \\
\hline $\begin{array}{l}\text { (A) } \\
\text { Ifem } \\
\text { No. }\end{array}$ & (B) Document/Drawing No. & $\begin{array}{l}\text { (C) Sheet } \\
\text { No. }\end{array}$ & $\begin{array}{l}\text { (D) Rev. } \\
\text { No. }\end{array}$ & (E) Title or Description of Data Transmitted & $\begin{array}{c}\text { Approval } \\
\text { Desig- } \\
\text { nator }\end{array}$ & $\begin{array}{c}\text { Reason } \\
\text { for Trans- } \\
\text { mittal }\end{array}$ & $\begin{array}{c}\text { Origi- } \\
\text { nator } \\
\text { Dispo- } \\
\text { stion }\end{array}$ & $\begin{array}{l}\text { Receiv- } \\
\text { er } \\
\text { Dispo- } \\
\text { sition }\end{array}$ \\
\hline 1 & $\mathrm{RPP}-5171$ & & 0 & Portable Exhauster & $\mathrm{N} / \mathrm{A}$ & 1 & 1 & 1 \\
\hline & & & & Position Paper & & & & \\
\hline & & & & & & & & \\
\hline & & & & & & & & \\
\hline & & & & & & & & \\
\hline & & & & & & & & \\
\hline & & & & & & & & \\
\hline
\end{tabular}

16.

KEY
Reason for Transmittal (G)

4. Review

5. Post-Review

6. Dist. (Receipt Acknow. Required)

\begin{tabular}{|ll}
\hline \multicolumn{2}{|c}{ Disposition (H) \& (I) } \\
$\begin{array}{ll}\text { 1. Approved } & \text { 4. Reviewed no/comment } \\
\text { 2. Approved w/comment } & \text { 5. Reviewed w/comment } \\
\text { 3. Disapproved w/comment } & \text { 6. Receipt acknowledged }\end{array}$ \\
\hline
\end{tabular}

SIGNATURE/DISTRIBUTION

(See Approval Designator for required signatures)

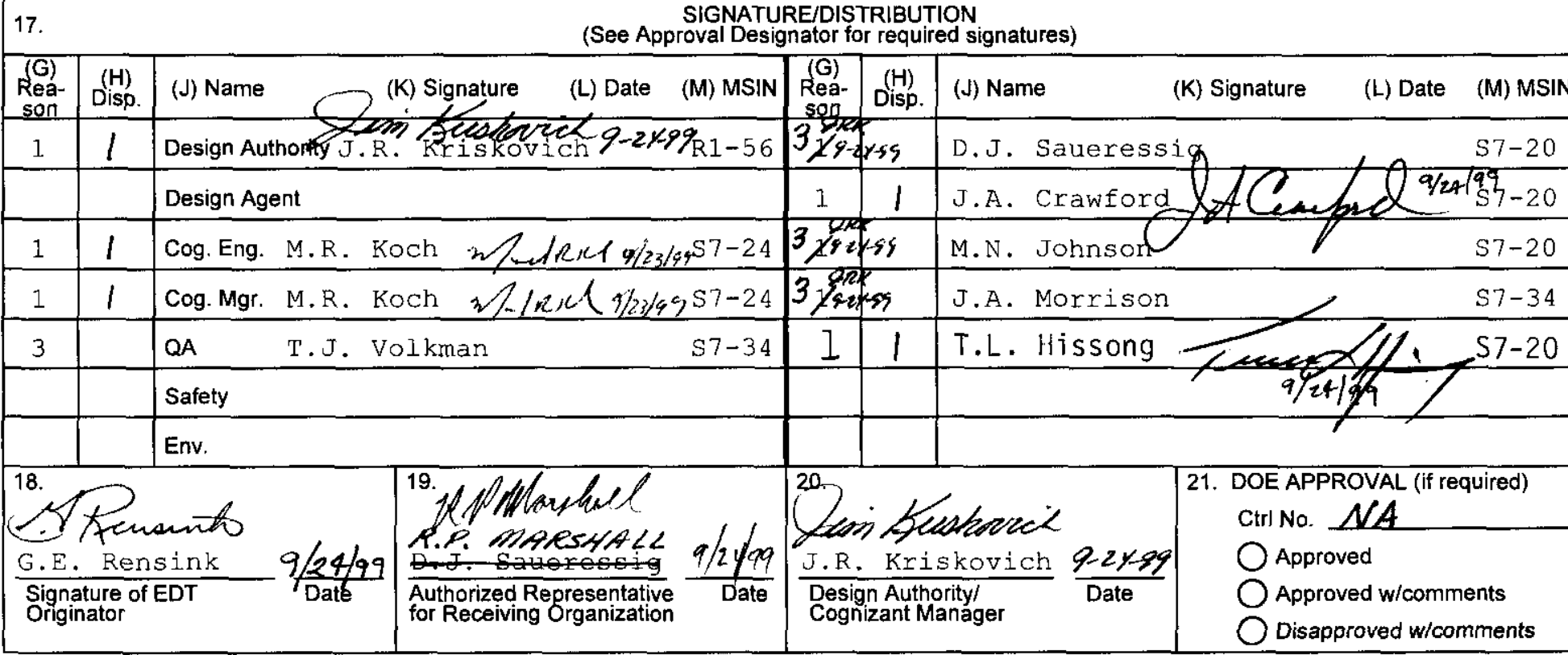




\title{
Portable Exhauster Position Paper
}

\author{
J. R. Kriskovich \\ LMHC, Richland, WA 99352 \\ Richland, WA 99352 \\ U.S. Department of Energy Contract DE-AC06-96RL13200 \\ $\begin{array}{lll}\text { EDT/ECN: } & 624840 & \text { UC: } 2000 \\ \text { Org Code: } & \text { LK820000 } & \text { Charge Code: } 103361 \\ \text { B\&R Code: } & \text { EW3130000 } & \text { Total Pages: } \$ 16 \text { s }\end{array}$
}

Key Words: Portable Exhauster, Saltwell Pumping, POR05 Skid C Portable Exhauster, POR05 Skid C, Saltwell Pumping

\begin{abstract}
:
This document identifies the tasks that are involved in preparing the "standby" portable exhauster (POR05 skid C) to support Interim Stabilization's schedule for saltwell pumping.
\end{abstract}

TRADEMARK DISCLAIMER. Reference herein to any specific commercial product, process, or service by trade name, trademark, manufacturer, or otherwise, does not necessarily constitute or imply its endorsement, recommendation, or favoring by the United States Government or any agency thereof or its contractors or subcontractors.

Printed in the United States of America. To obtain copies of this document, contact: Document Control Services, P.O. Box 950, Mailstop H6-08, Richland WA 99352, Phone (509) 372-2420; Fax (509) 376-4989.
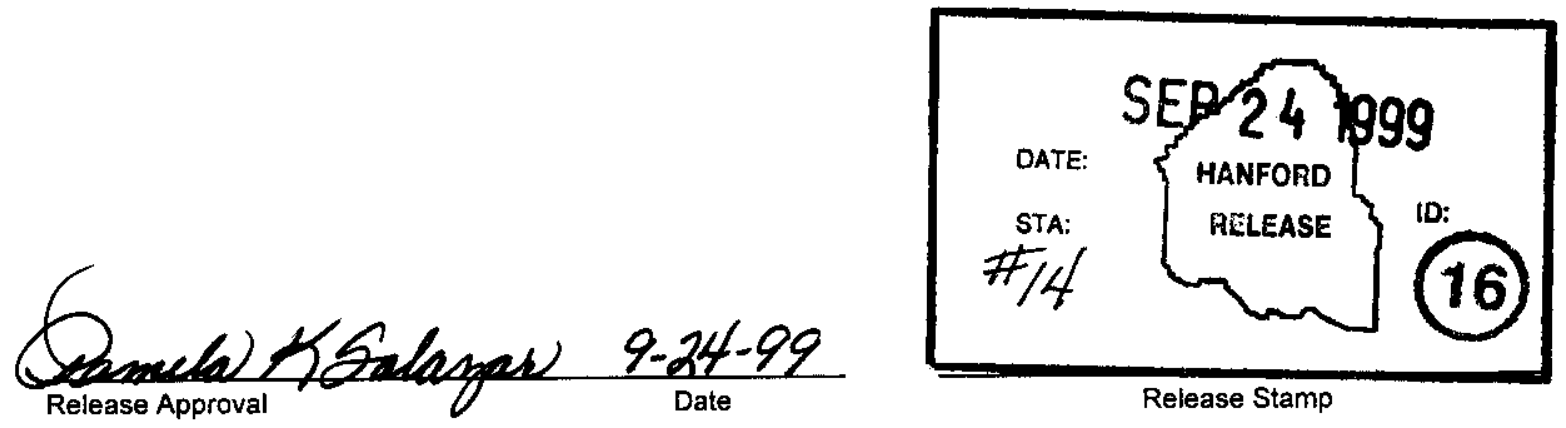

\section{Approved For Public Release}




\title{
Portable Exhauster Position Paper
}

\author{
RPP-5171, Rev. 0
}

Jim Kriskovich

Lockheed Martin Hanford Corporation

September 24, 1999 
RPP-5171

Revision 0

\section{Table of Contents}

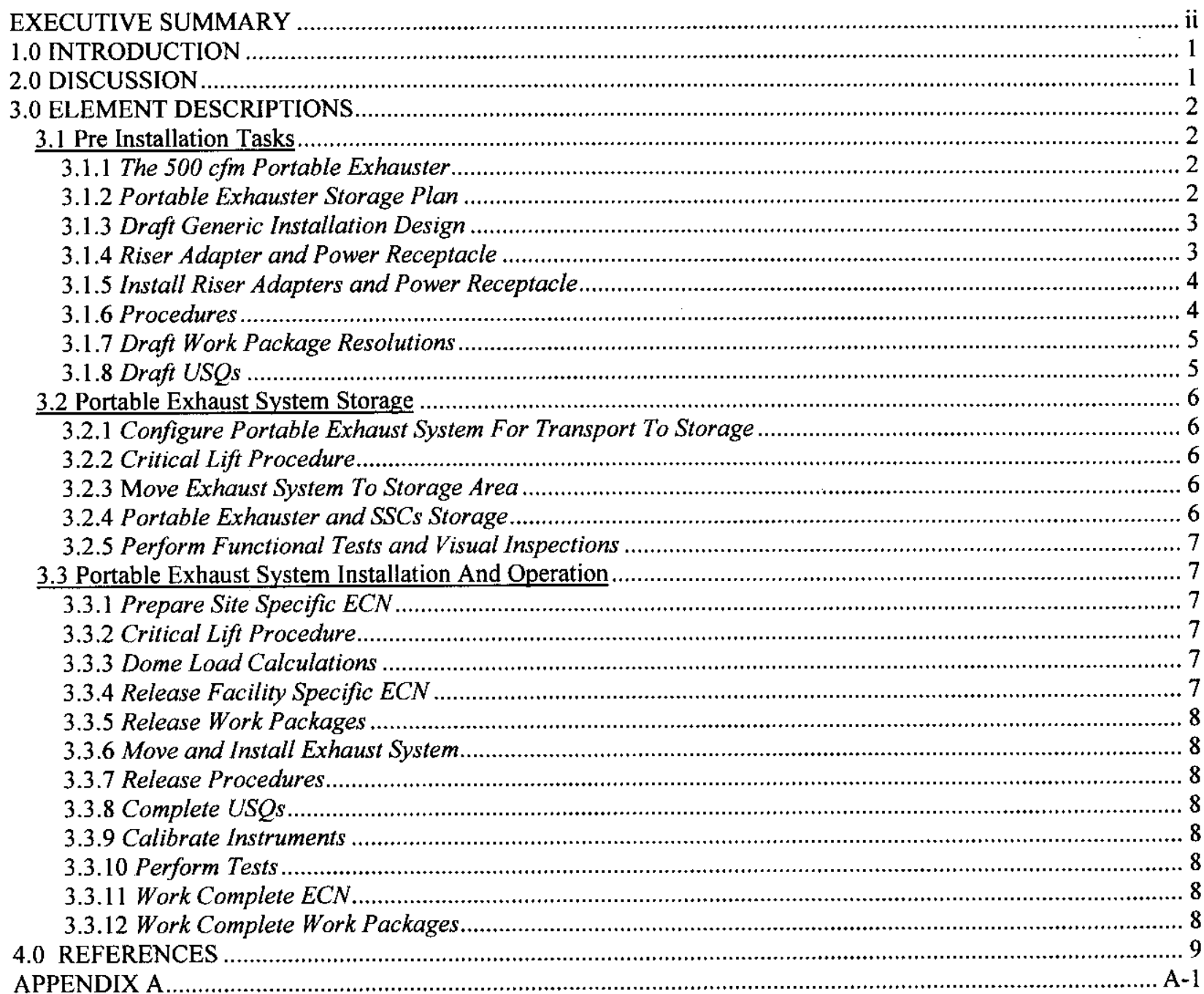




\section{EXECUTIVE SUMMARY}

A standby portable exhaust system will be assigned to any facility scheduled to be saltwell pumped with the exception of 241-S farm, 241-SX farm or 241-T farm. The standby portable exhauster shall be prepared for use and placed in storage. The standby portable exhaust system shall be removed from storage and installed to ventilate tanks being pumped that reach $25 \%$ LFL. There are three tasks that are evaluated in this document. Each task shall be completed to support portable exhaust system installation and operation (see sections 1.0, 2.0 for details). They are:

- Pre Installation Task.

- Portable Exhaust System Storage Task.

- Portable Exhaust System Installation and Operation Task

Pre Installation Task - To reduce the time required to ventilate a tank if $25 \%$ LFL is reached, the following elements need to be addressed and completed as described in this document to declare a portable exhauster ready to install and to declare readiness to begin saltwell pumping (see section 3.1 for details):

- Identify a portable exhaust system available for immediate use.

- Prepare and release riser adapter and power receptacle ECN, work package, and USQ.

- Install riser adapters and facility power receptacle or portable generator.

The following only need to be identified and a draft prepared as described in this document:

- Prepare and release portable exhaust system storage plan.

- Prepare and release generic portable exhaust system installation drawing(s) and USQ.

- Prepare procedures (operating procedure, CAM functional test).

- Prepare draft work package resolutions (calibration, installation, testing).

- Prepare draft USQs

Portable Exhaust System Storage Task - The portable exhaust system POR05 Skid C will be assigned to support each of the remaining facilities to be saltwell pumped. The exhaust system will be stored in accordance with the exhaust system storage plan (i.e., PMS data sheet instruction, work package instructions). The following elements to be performed in preparation for storage and during storage should be addressed and completed as described in this document (see section 3.2 for details). These items do not need to be completed prior to declare readiness to begin saltwell pumping:

- Configure portable exhaust systems for transport to storage as specified in the storage plan.

- Prepare and release critical lift procedure (supports exhaust system storage).

- Move exhaust system to storage area.

- Portable exhauster and SSCs Storage.

- Perform periodic functional test, visual inspections, and verify installation hardware available during storage.

Portable Exhaust System Installation And Operation - The portable exhaust system will be removed from storage and installed on a tank being saltwell pumped if flammable gas levels in the vapor space 
reach $25 \%$ LFL. The elements to install and declare an exhaust system operational will be completed only after Interim Stabilization initiates installation (see section 3.3 for details). The elements include:

- Prepare and release facility specific installation ECN.

- Develop critical lift procedure (supports installation).

- Perform dome load calculations.

- Release work packages.

- Move exhaust system from storage and install exhaust system.

- Release procedures.

- Complete USQs.

- Calibrate instruments.

- Perform tests (OTP, CAM functional test, aerosol tests, vapor sample test, flow test)

- Sign ECN(s) work complete.

- Work complete work packages. 
RPP-5171

Revision 0

\subsection{INTRODUCTION}

A $500 \mathrm{cfm}$ portable exhauster was developed for Interim Stabilization as a result of flammable gas safety concerns and is required to support saltwell pumping tanks. This plan describes the elements of storage, transportation, installation, testing, and operation that shall be addressed prior to declaring portable exhaust systems ready to support saltwell pumping. This plan also identifies elements that shall be addressed and completed prior to declaring portable exhaust systems operational after the system is installed on a tank.

\subsection{DISCUSSION}

As stated above, a single $500 \mathrm{cfm}$ portable exhauster is required to support Interim Stabilization's schedule for saltwell pumping. It should be noted, portable exhaust systems are currently installed in 241-S farm and on tank 241-A-101. The portable exhaust system in 241-S farm is tested and may be placed in service at any time. The portable exhaust system installed on tank 241-A-101 must be removed for upgrade purposes (stack sample system) prior to ventilating a tank. Tanks in 241-SX farm and 241-T farm are actively ventilated and as a result will not require portable exhaust system support during saltwell pumping.

The transition window to active ventilation is aggressive (approximately 6 days, see DE-AC0696RL13200 and LMHC-9952014AR1) considering the tasks that must be completed. There are numerous elements associated with each task that need to be addressed and some completed as described in this document prior to declaring readiness to saltwell pump. The elements include:

- Preparing a $500 \mathrm{cfm}$ portable exhaust system for use.

- Preparing a draft generic installation design.

- Preparing draft procedures.

- Preparing draft work package resolutions.

- Preparing draft USQ's.

- Preparing tank riser adapter ECN's, facility power ECNs, and order associated materials.

- Preparing tank risers for connection to exhauster duct and inlet filter duct by adding riser adapters, isolation valves and blind flanges.

- Installing a power receptacle or obtaining a portable generator.

The 6 day transition will require around the clock $(24 \mathrm{hr}$.) commitment from organizations within Interim Stabilization (i.e., engineers, operators, craftsman, HPTs, planners, safety, quality) to support this schedule. It addition, organization outside of Interim Stabilization (i.e., facility cognizant engineers, Vent and Balance, and Crane \& Rigging) will be needed to support a portable exhaust system installation. An exhaust system installation must be made the number one schedule priority with the groups mentioned above if the installation is expected to be completed within 6 days. To provide active ventilation certain activities are required but are not limited to, the following (see schedule in Appendix A):

- Release procedures and work packages

- Remove the "standby " portable exhauster, inlet filter and supporting SSC (structures, systems, and components) from storage and transport to the affected tank for installation. 
- Connect an exhauster (POR05 Skid C) and inlet filter to tank riser adapters via flexible duct or rigid duct and isolation valves.

- Connect the exhauster to a facility power receptacle or portable generator.

- Perform exhaust system instrument calibrations and operational tests.

NOTE: The standby exhaust system discussed in this document is limited to ventilating single tanks only. The standby exhaust system will not be connected to the facility data highway or interlocked electronically to the saltwell pumping skid. Operations will be required to verify the saltwell pump locked out as a start up measure for exhauster operation on a tank. Conversely, operations will be required to verify the standby exhaust system locked out and isolated from the tank as start up measure to commencing saltwell pumping.

\subsection{ELEMENT DESCRIPTIONS}

\subsection{Pre Installation Tasks}

\subsubsection{The $500 \mathrm{cfm}$ Portable Exhauster}

Site Fabrication Services will provide a $500 \mathrm{cfm}$ portable exhauster (POR05 Skid C) to Interim Stabilization. The portable exhauster will be acceptance tested and green tagged to demonstrate that the functional requirements for portable exhausters to be used in support of saltwell pumping were met. These activities will be completed to demonstrate readiness to saltwell pump.

Site Fabrication Services and Interim Stabilization will perform the 168 hour airflow test, preferably at Site Fabrication Services' shop. The exhauster will be transported from Site Fabrication Services' shop to Interim Stabilization's storage area in accordance with critical lift procedure and work package instructions. Interim Stabilization will direct the transport activities to the storage area. These activities will be completed a soon as possible. However, they are not required to show readiness to saltwell pump.

\subsubsection{Portable Exhauster Storage Plan}

There are several different methods that can be utilized to establish and implement elements of a storage plan. The elements may be developed and released in a Supporting Document, as work instructions in a work package, or as instructions on PMS data sheets.

A storage plan (i.e., work package instructions or PMS data sheet instructions) will be developed to identify exhauster configuration for storage. The exhauster inlet and outlet ports will be covered, water in the seal pot and seal pot drain system will be removed (performed by Site Fabrication Services), and the exhaust stack will be installed (performed by Interim Stabilization).

Note: Interim Stabilization will install the exhaust stack after the exhauster is delivered to storage. The exhauster can not be transported with the exhaust stack installed. 
The storage plan will identify tasks that will be performed during storage. A functional test will be performed (every 6 months) to confirm system operation. Periodic visual inspections will be performed to confirm no adverse affects to SSC's resulting from exposure to the elements. Preventive maintenance and winterization maintenance will not be required and exhaust system instruments will not be calibrated while the exhauster is in storage. The storage plan will identify a power source to support portable exhauster operation during functional testing.

There are several exhaust system SSCs supplied by Interim Stabilization. These items (i.e., flexible duct, fasteners, electrical conductor) will be identified in the storage plan and will be transported to the portable exhauster storage area.

The storage plan will be developed as soon as possible. However, it is not required to demonstrate readiness to saltwell pump.

\subsubsection{Draft Generic Installation Design}

Interim Stabilization Engineering will prepare a draft generic $500 \mathrm{cfm}$ portable exhaust system installation drawing(s). The exhauster location and risers noted in the draft generic design will not correspond to a specific tank. The location and risers noted shall represent all tanks scheduled to be saltwell pumped. The design will include a $500 \mathrm{cfm}$ portable exhauster positioned next to a tank riser. The exhauster will be connected to a riser via flexible or rigid duct, riser spool piece, flanges, gaskets, isolation valves and fasteners. The generic design will also include an inlet filter housing placed next to a tank riser. The inlet filter housing will be connected to a tank riser via rigid duct, riser spool piece, flanges, gaskets, isolation valves, and fasteners. A parts list will be prepared and general notes will be included which reference installation and testing instructions.

The draft generic installation drawing(s) will be prepared prior to declaring readiness to saltwell pump.

\subsubsection{Riser Adapter and Power Receptacle}

Riser Adapters - Tank risers will be modified to include adapters. The adapters are designed to provide an isolation point and a quick connection point for the exhauster duct and inlet filter duct. The adapters are prefabricated assemblies supplied by Site Fabrication Services. The adapter components include gaskets, flanges, pipe, isolation valve, blind flange, and fasteners. The fasteners that secure the adapters to tank risers will be supplied by Interim Stabilization. The adapters shall be installed on tank risers to demonstrate readiness to saltwell pump. The elements include:

- Prepare and release ECN to install tank riser adapters.

- Order riser adapter components.

- Prepare and release work package to fabricate riser adapters.

- Prepare and release USQ for riser adapter work package.

Power Receptacle Or Portable Generator - A modification will be performed to provide the required power needed to operate a $500 \mathrm{cfm}$ portable exhauster within a facility. The power receptacle 
components will be supplied by Interim Stabilization. The components include conductors, a circuit breaker, conduit, mounting brackets, and a receptacle. The elements include:

- Identify portable exhauster power supply (portable generator or facility supplied)

- Prepare and release ECN for facility power connection.

- Order power connection components.

- Prepare and release work package to install facility power connection or place portable generator.

- Prepare and release USQ for power connection work package.

NOTE: if power is unavailable within the facility a portable generator will be employed to provide the service needed to power a portable exhaust system. The power receptacle shall be installed or a portable generator shall be identified to demonstrate readiness to saltwell pump.

\subsubsection{Install Riser Adapters and Power Receptacle}

The riser adapters and power receptacles shall be installed as described in the ECN(s) and work package instructions.

Note: ECNs and work packages, which were prepared to install riser adapters and power receptacles may not be work completed prior to commencing saltwell pumping. The ECNs and work package resolutions prepared for this task may include modifications for several tanks within a facility (tanks schedule for future pumping). A cognizant engineering manager or design authority may elect to work complete these activities on a tank by tank basis by a letter of correspondence. A letter of correspondence, rather than work completing ECN(s) and the work package, will be accepted to demonstrate readiness to saltwell pump.

\subsubsection{Procedures}

The following procedures will be prepared but not released for the standby portable exhauster. They include:

- PMS data sheets.

- Operating procedure.

- CAM functional test procedure.

- Aerosol test intake filter.

- Aerosol test exhauster.

- Vapor sample exhauster.

- Flow test exhauster.

A draft copy of each procedure mentioned above will be prepared for walkdown and approvals. It should be noted, the interpretation of a procedure walkdown is that they are performed on installed systems only. Therefore, the procedures may not be released prior to a portable exhaust system installation. At a minimum, a draft copy of each procedure is needed to demonstrate readiness to saltwell pump.

Interim Stabilization shall store draft procedures in Procedure Information (PROC INFO) on Transfer Drive. 


\subsubsection{Draft Work Package Resolutions}

Draft work package resolutions will be prepared to support a portable exhauster and inlet filter installation. Draft work package resolutions will be prepared for the following:

- Installation/OTP work package (one package will cover the exhauster and inlet filter installations).

- Calibration work packages (for the exhauster and inlet filter).

- Aerosol test work packages (one for the exhauster and one for the inlet filter).

- Vapor sample work package (exhauster specific).

- Flow test work package (exhauster specific).

- Prepare CAM functional test work package.

Interim Stabilization will insure the work packages resolutions identified above are entered into JCS with a status "retention inactive".

Draft resolutions will be prepared for each work package identified above to demonstrate readiness to saltwell pump.

\subsubsection{Draft USQs}

Draft USQ screenings will be prepared for the procedures identified in section 3.1.6 and the installation work package identified in section 3.1.7.

Draft USQ screenings will be prepared to demonstrate readiness to saltwell pump. Interim Stabilization shall designate a cognizant engineer or design authority responsible for holding the draft USQs identified above. 
RPP-5171

Revision 0

\subsection{Portable Exhaust System Storage}

\subsubsection{Configure Portable Exhaust System For Transport To Storage}

Portable exhauster POR05 Skid C will be configured by Site Fabrication Services in a "standby" configuration for transport from Site Fabrications Service's shop to Interim Stabilization's storage area. The standby configuration performed by Site Fabrication Services is described in the storage plan (see section 3.1.2). Completing this is not required prior to declaring readiness to saltwell pump.

\subsubsection{Critical Lift Procedure}

A critical lift procedure will be developed to support portable exhauster transport activities from Site Fabrications Service's shop to Interim Stabilization's storage area. This procedure will be completed before the portable exhauster is transported. The procedure is not required to show readiness to saltwell pump.

\subsubsection{Move Exhaust System To Storage Area}

The exhauster, inlet filter, and exhaust system SSCs will be moved from Site Fabrications Service's shop to Interim Stabilization's storage area as specified in the storage plan (see section 3.1.2). Interim Stabilization shall direct portable exhaust system transportation activities.

There are several components (i.e., flexible duct) that are supplied by Interim Stabilization. These SSCs will be identified in the storage plan and will be transported to the storage area discussed above. Completing this is not required prior to declaring readiness to saltwell pump.

\subsubsection{Portable Exhauster and SSCs Storage}

The exhauster will be configured for storage by Interim Stabilization as specified in the storage plan (see section 3.1.2). The exhaust stack will be installed to support periodic functional tests. Interim Stabilization shall provide a power service (power receptacle or portable generator) to support functional testing.

Miscellaneous SSC's provided by Site Fabrication Services will be stored with the standby exhauster. The components will include duct flanges, duct supports, and inlet filter. Miscellaneous SSC's provided by Interim Stabilization will be stored with the standby exhauster. The components include duct fasteners, duct gasket material, flexible duct, rigid duct, grounding materials, power conductor, and power plug. These SSCs will be referenced and their storage location noted in the storage plan

Collecting and storing the components discussed above will be completed as soon as possible. However, completing this activity is not needed to demonstrate readiness to saltwell pump. 


\subsubsection{Perform Functional Tests and Visual Inspections}

Interim Stabilization will perform periodic functional test and visual inspections of the portable exhauster and SSCs during storage. The tests and inspections will be performed as specified by the storage plan (see section 3.1.2).

\subsection{Portable Exhaust System Installation And Operation}

The items listed in this section represent task elements that must be addressed and completed to declare a portable exhaust system operational. The tasks include system installations, calibrating components and system tests. These elements will only be addressed and completed to support a portable exhaust system installation.

The activities identified below are not required to be complete before declaring readiness to saltwell pump.

\subsubsection{Prepare Site Specific ECN}

A site specific ECN will be developed to supplement the generic design referenced in section 3.1.3. The ECN will change facility tank specific design media to reflect the portable exhaust system component installations. The ECN will reference the generic installation drawing(s) that describes installation details.

This ECN must be prepared and dome load calculations developed to support a portable exhaust system installation.

\subsubsection{Critical Lift Procedure}

A critical lift will be developed to support the transport activities from Interim Stabilization's storage area to a tank. The critical lift procedure will be complete prior to moving the exhauster.

\subsubsection{Dome Load Calculations}

Dome load calculations will be performed after the facility specific ECN is released (see section 3.3.1). The dome load calculations will be completed before the exhaust system is installed in a facility to support saltwell pumping.

\subsubsection{Release Facility Specific ECN}

Release the facility specific ECN described in section 3.3.1. This ECN will be released before the exhaust system is installed on a tank. 


\subsubsection{Release Work Packages}

The work packages identified in section 3.1 .7 will be released to support exhaust system installation and operation.

\subsubsection{Move and Install Exhaust System}

The exhaust system (exhauster, inlet filter, ducting) will be moved from storage and installed on a tank as directed by Fluor Daniel Hanford, or its delegated subcontractor to support stallwell pumping a tank that has reached 25\% LFL (see DE-AC06-96RL13200 and LMHC-9952014AR1).

\subsubsection{Release Procedures}

The procedures drafts identified in section 3.1.6 will be released to support portable exhauster operation and testing.

\subsubsection{Complete USQs}

Complete USQs listed in section 3.1.8.

\subsubsection{Calibrate Instruments}

Calibrate instruments installed on the portable exhauster and inlet filter.

\subsubsection{Perform Tests}

Perform test listed in section 3.1.6.

\subsubsection{Work Complete ECN}

ECN listed in section 3.3.4 will be work completed before placing the exhaust system in service.

\subsubsection{Work Complete Work Packages}

Work packages listed in section 3.1 .7 will be work complete before placing the exhaust system in service. 


\subsection{REFERENCES}

DE-AC06-96RL13200, Further Interpretation For Portable Exhauster Installation Contained Within The Saltwell Pumping Safety Evaluation Report, Revision 0, Dated 06/22/99, Department of Energy, Office of River Protection, Richland, Washington

LMHC-9952014AR1, Response TO: "Subcontract Number 80232764-9-K001; U.S. Department of Energy, Richland Operations Office Interpretation For Portable Exhausters Installation Contained Within The Saltwell Pumping Safety Evaluation Report, Revision 0", Lockheed Martin Hanford Corporation, Richland, Washington. 
RPP-5171

Revision 0

\section{APPENDIX A}




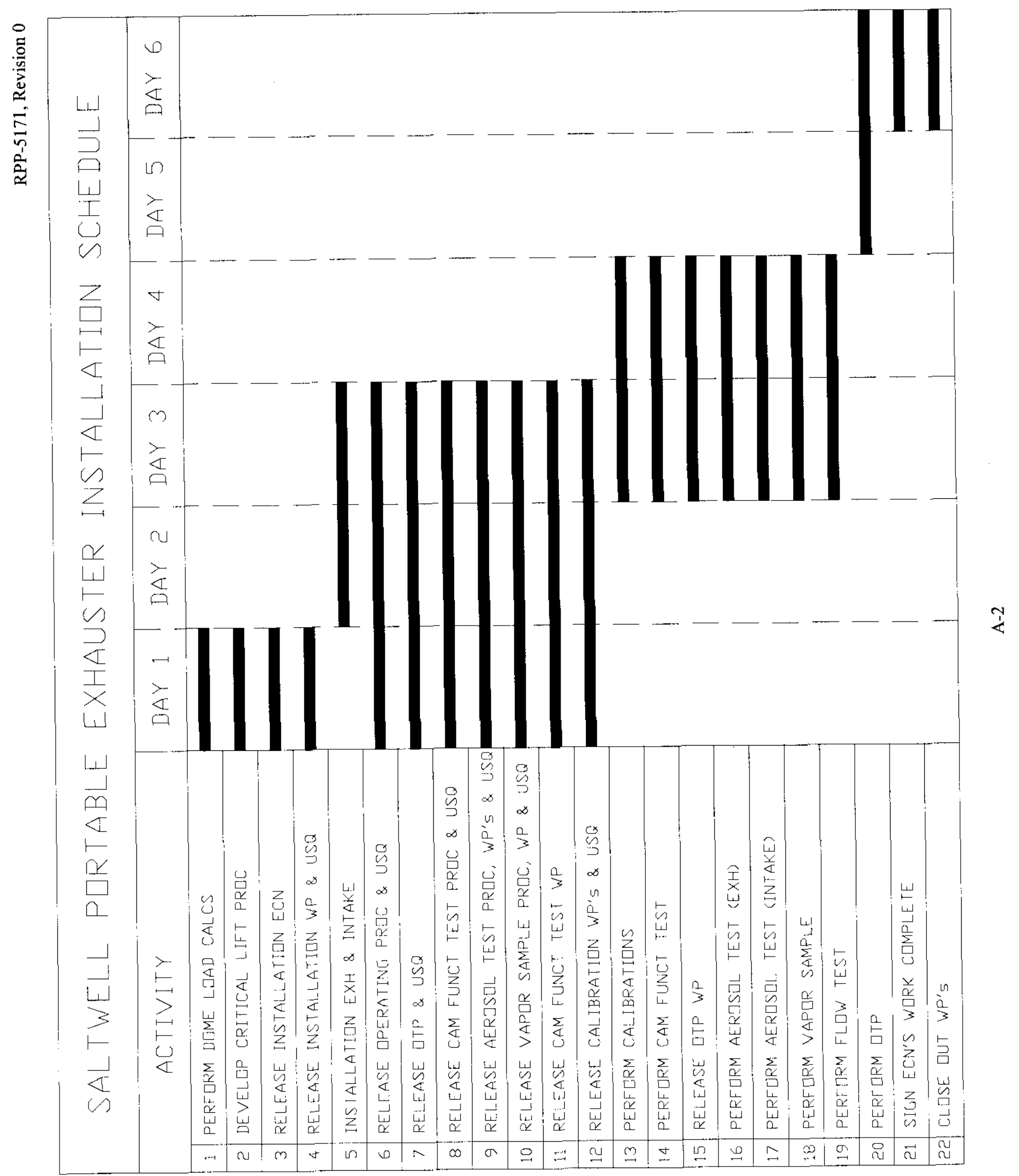

